ISSN 1991- 8690

Website: http://jsci.utq.edu.iq
1991 - 8690 الترقيم الدولي

Email:utjsci@utq.edu.iq

\title{
The Study of Electrical Properties and Photocurrent of Polyaniline/ fluorescein films.
}

\author{
Hameed A. Hamadi \\ Basrah University - Polymer Research Center \\ Materials Science Department.
}

\begin{abstract}
Electrical conductivity and visible photo current (PC) measurements have been performed on thick film $(10 \mu \mathrm{m})$ of polyaniline modified with $\left(1 \times 10^{-4} \mathrm{~mole}\right)$ content of fluorescein organic dye were all measurements have been made using Sandwich structure of aluminum and semitransparent aluminum with area $\left(0.03 \mathrm{~cm}^{2}\right)$ circular electrode. The D.C. conductivity was measured as a function of doping ratio with iodine using the technique of two probes.All current measurements have been made at steady state conditions were the obtained results showed that the domain conduction mechanisms was identified as space charge limited current (SCLC) and the D.C. bulk conductivity of pure

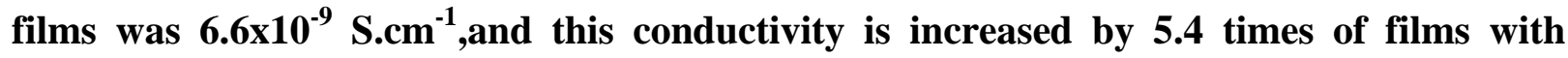
doping ratio equal to $2 \%$. Photocurrent (PC) was measured with specified wave length as a function of applied voltage were the intensity of the incident light was $295 \mathrm{lux} / \mathrm{m}^{2}$ for each case. The obtained results of PC showed that the observed photons form excites, and the caste films have poor photoconductivity while maximum peak of D.C. conductivity under illumination was obtained near Yellow region of visible light were the absorption of incident light is high and free carriers are available.

Also the obtained results showed that the cut-off wave length is near red region, and the recombination process is bulk finally Another noticeable remark, that the photocurrent is increased by amount of 800 times \& D.C conductivity is increased by 1300 comapred to maonitude at darkness.
\end{abstract}




\section{Introduction:}

At the end of the seventies organic conjugated polymers emerged as very attractive materials after the discovery that their electrical conductivity could be increase by several orders of magnitude upon chemical of electrochemical treatment (traditionally referred to as doping in analogy to the physics of semiconductors) ${ }^{(1)}$. Extensive theoretical and experimental studies initially addressed the properties of transpolyacetyline $^{(2)}$ and than shifted towards more environmentally stable conjugated chains such as poly(para-phenylene) (PPP), poly(para-phenylene vinylene) (PPV), polythyophene (PT), and polyaniline, which incorporated aromatic rings it to their backbone $^{(3)}$.In 1990, the first report of electroluminescence from PPV ${ }^{(4)}$ renewed the interest in conjugated polymers and opened the way to the fabrication of electro-optic devices by exploiting their semiconducting properties and high luminescence yield. Efficient organic light-emitting diodes (LEDs) ${ }^{(5-7)}$ are now available in the whole UVVIS range and they are almost into the commercialization stage ${ }^{(8-10)}$.Conjugated polymers are also used as active element in light-electrochemical cell ${ }^{(11)}$, photodiodes ${ }^{(12 \text {, }}$ 13), and solid-state lasers ${ }^{(14)}$.

Polyaniline is one of the conducting polymers that has attracted considerable one of the best conduits for the preparation of polymer-based conducting polymer composites ${ }^{(14-}$ ${ }^{15)}$, because of that PANI high stability toward air and moisture, high electrical conductivity $^{(16)}$ and unique red ox properties $^{(17)}$, recently, significant progress of PANI have been achieved in the preparation of processable form (18). Another advantage is that it is both melt and solution processable. This means that the compound can be easily mixed with convential polymers and that is easy to fabricate polyaniline products in to required shapes. More even products consisting of polyaniline compounds can be easily disposed of without environmental risks (19).

The most important domain in applications of conducting blends is in static materials conductivities of antistatic applications needs to be high $\left(10^{-6}-10^{-5}\right) \mathrm{S} / \mathrm{cm}$ ranges are Fluorescein is a crystalline powder coloured red sufficient ${ }^{(17,18)}$.

to reddish-brown, soluble in water. It belongs to the group of xanthene dyes. it belongs to the group of acid dyes and constitutes fluorescein disodium salt soluble in sea water with extremely intense green fluorescene ${ }^{(20)}$.This organic dye has many uses so a fluorophore is commonly used in microscopy, in type of of dye laser as the gain medium ,in forensics and serology to detect latent blood stains, and in dye tracing. Fluorosceine has an absorption maximum at $494 \mathrm{~nm}$ and emission maximum of $521 \mathrm{~nm}$ (in water).Also Fluoresciene has an isosbestic point (equal absorption for all $\mathrm{pH}$ values ) at $460 \mathrm{~nm}$. Fluoresiene is also known as a color additive ( D \& C Yellow no.7). The disodium salt form of fluoresciene is known as D\&C Yellow no. 8 (21-23)

A large amount of the published data of photo conduction polymers refers to sensitized or doped materials, in this article, molecular species such as dyes of Fluorisine is added to host conducting polymer, polyaniline 


\section{Experimental:}

Films of polyaniline modified with fluorescein have been prepared by casting method using aluminum substrate of $(1.5 \times 1.5) \mathrm{cm}^{2}$ area as a lower electrode were a solution made of( 0.1 mole of polyaniline and $1 \times 10^{-4}$ mole of fluorescein organic dye using Dmso as asolvent) used for this purpose. All prepared films dried at room temperature for 24 hours, after that heated gradually up to $80^{\circ} \mathrm{C}$ for one hour to complete curing. Semi transparent aluminum layer were evaporated on top of (polyaniline) as an upper electrode through a circular mask $\left(0.03 \mathrm{~cm}^{2}\right)$ to complete the sample were the deposition of Aluminum metal (99.99) was carried out using evaporation system model (Varian 3117) under vacuum pressure more than $\left(10^{-6}\right)$ torr the sandwich configuration (Aluminum /polymer / Aluminum) was used to study the electrical properties of the films

The D.C. bulk conductivity measurements were carried in dark and electrical shield. Stationary photo current measurements were taken by applying a voltage to the sample and measuring both current in dark and under illumination using circuit shown in figure (1)

A tenxtine lamp type Philips 120 watt was used to obtain photo current of illumination intensity $295 \mathrm{lux} / \mathrm{m}^{2}$. The effect of increasing the incident light wave length on photo current was measured using the circuit shown in figure (1) and figure (2).All measurements and electrical conductivity of the blend were made at different doping ratio with iodine via two probes technique

\section{Results and discussion:}

D.C conductivity of the polymer blend were measured at steady state conditions as shown in figure (3) which shows the variation of current as a function of time this phenomenon may be explained due to the heat effect which activates the remaining traces of the solvent in the film and also due to the movement of the polymers chains at the moment of applying external field and the current was estimated as afunction of doping ratio as shown in Figure (4) which shows the relation between current versus voltage at different doping ration were at low voltage range a linear relation was obtained indicating that the caste film obeys ohm's law since thermally generated charge carriers are effected by currents limits ${ }^{(19)}$.The bulk conductivity have been calculated according to value of resistance and sample dimensions , having the bulk conductivity $\left(6.6 \times 10^{-9}\right.$ )S.cm ${ }^{-1}$ with pure case while maximum D.C conductivity was obtained at doping ratio equal to $2 \%$ equal to $3.6 \times 10^{-9} \mathrm{~S} \mathrm{~cm}^{-1}$ due to the increase of free charge carriers while at doping ratio over $2 \%$ less free charge carriers are available due to the increase of the traps in both kinds shallow and deep which reduce mobility of charge carriers as it obvious in figure (5).

Figure(6) shows the relationship between current and voltage on a log-log scale were this figure is telling that at higher voltage ohm's law is no more valid which indicates that the injected electrode carriers are greater than the thermally generated charges thus ohm's law is no more sufficient, more conduction mechanisms for the charge transfer is possible to occurs so it is clear From the obvious figures, the most possible conduction mechanisms were found to be Space charge limited current (SCLC), this conduction mechanism is given by the following relation ${ }^{(25)}$ : 


$$
J=\frac{9}{8} \mu_{o} \varepsilon_{0} \xi \theta\left(v^{2} / d^{3}\right)
$$

Where:- $\quad \xi=$ the dielectric constant for polymer.

$\xi_{\circ}=$ the permittivity of free space.

$\mu_{\circ}=$ the electron mobility in the conduction band.

$v$ is the applied voltage

$d=$ thickness of used film

$\boldsymbol{\Theta}=$ the ratio of free holes $\left(\mathrm{P}_{\circ}\right)$ in the valence band to the total holes density $\left(\mathrm{P}_{\text {。 }}\right.$ $\left.+\mathrm{P}_{\mathrm{t}}\right)$.

. Thus in the first low region of such behavior of SCLC , The current is related to voltage according to the relation (I $\alpha \mathrm{V}^{\mathrm{n}}$ ) when(n>2 ) see figure(3) and figure(6) so when there are not enough compensation charges available and it's magnitude determined largely by the presence of localized state that trap and store charges, the second square region $\mathrm{V}_{\mathrm{TFL}}$ (Trap fill level) are started .Figure (7) shows the relation between $\boldsymbol{\Theta}$ and the doping ratio, here $\theta$ reflects. The extent to which traps reduce the effective mobility ( $\left.\mu_{\text {eff }}\right)$ of charges and can be estimated from the following relation $^{(25)}$ :

$\boldsymbol{\theta}=\mathrm{P}_{\circ} /\left(\mathrm{P}_{\circ}+\mathrm{P}_{\mathrm{t}}\right)=\mathrm{I}_{1} / \mathrm{I}_{2}$

Where $\mathrm{P}_{\circ}$ is free holes

$\mathrm{Po}+\mathrm{P}_{\mathrm{t}}$ is total holes density

$P_{t}$ is density of the trapped holes

$\mathrm{I}_{1}$ is the current at critical voltage at which the transition to SCLC behavior is occurring. $\mathrm{I}_{2}$ is the current at the end of the rise.

Using the circuit shown in figure (2) to study photocurrent measurements were all current-voltage characteristics of the films were made under dark \& illumination conditions current as a function of the applied voltage and the obtained results are shown in figure (8).In general the current variation and photo conductivity under illumination is relativity small which means poor photoconduction and another result is observed were increasing conductivity of caste film by creating electronic transition in the band gap have been observed, this is obvious with short wave length near to green light of visible light while moving toward yellow region of incident light leading to increase of photoconductivity, this increase can be explained in the form of the increase in the number of free charge carriers (electrons \& holes), and partially a decrease in the potential barrier at the grain boundaries, more ever, With further increasing of wave length of incident light (near to red region of visible light) photo conductivity is decrease and this may explain according to less number of charge carriers velocity \& mobility at grain boundaries leading to high transit time and less drift, and less photo conductivity since no more light reaching the active region in depth of the thick film and also more light is reflect from the surface of polyaniline films (less absorption coefficient).

This behavior is obvious in figure(9) which shows the variation of D.C. conductivity under illumination as a function of wave length. Were this figure showing that the absorption of incident light is greater at wave near to yellow region of the visible light were free carrier density increases $\&$ thus might fill most the capture centers, leading to increasing in photocurrent. While maximum peak in conductivity is made at wave length near to yellow region of visible light, this is due to the high absorption coefficient at this range of wave length. 


\section{Conclusion:}

Electrical properties of polyaniline modified with fluorescein have been studied through measuring (current-voltage) characteristic. The conducting mechanism was space charge limited current and highest conductivity was $35.64 \times 10^{-9}{\mathrm{~S} . \mathrm{cm}^{-1} \text { at }}^{-1}$ doping ratio $2 \%$ with iodine approaching semiconductor behavior, and traps states changes according to doping ratio.

All the prepared polymeric films show semiconductor behavior. The photocurrent of thick film using illumination through upper aluminum semi transparent, up on absorption excisions are formed in the polymer (polarons) which gives rise to a photocurrent. The photocurrent increases with increasing wave length from green region to yellow region of visible light since we have peak conductivity and photocurrent meaning the highest absorption coefficient, while in wave length near to red region we get the cut-off wave length.

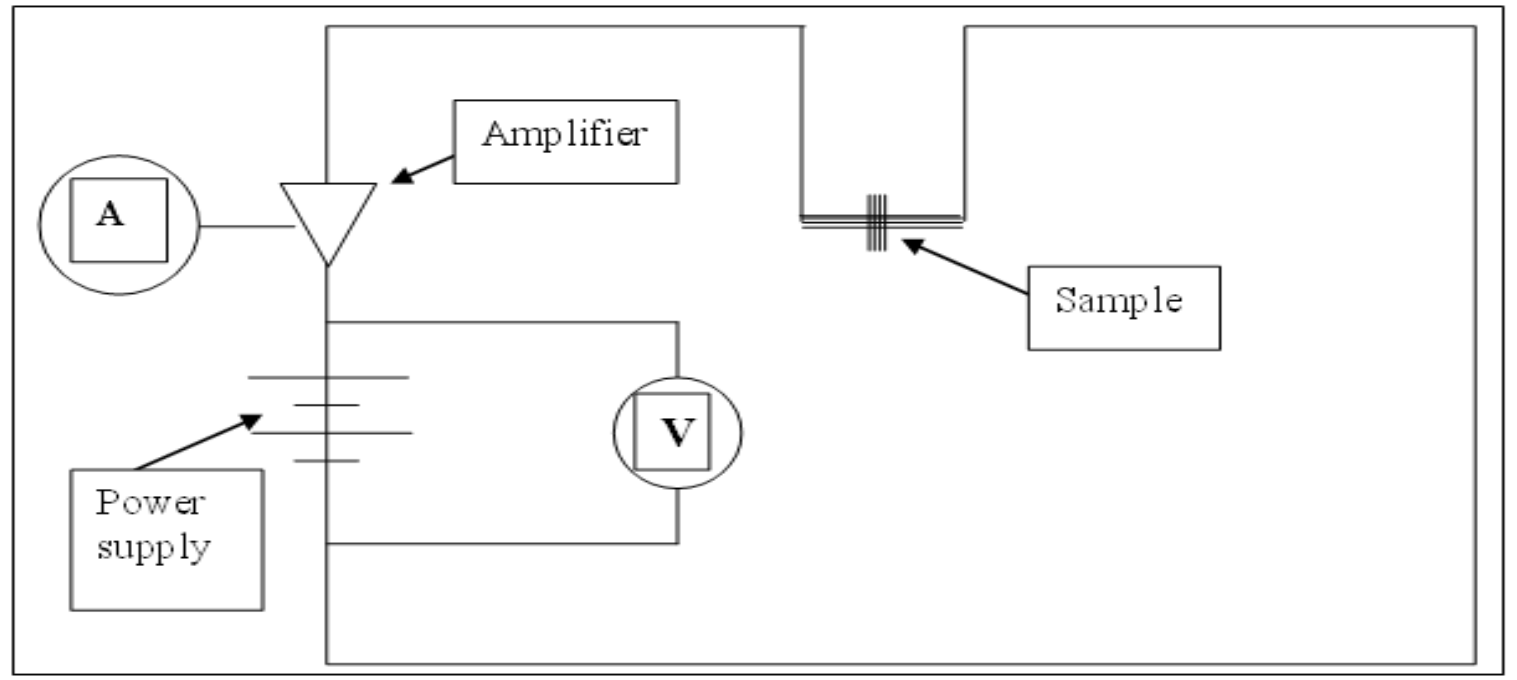

Fig (1) the Circuit of measuring dc conductivity

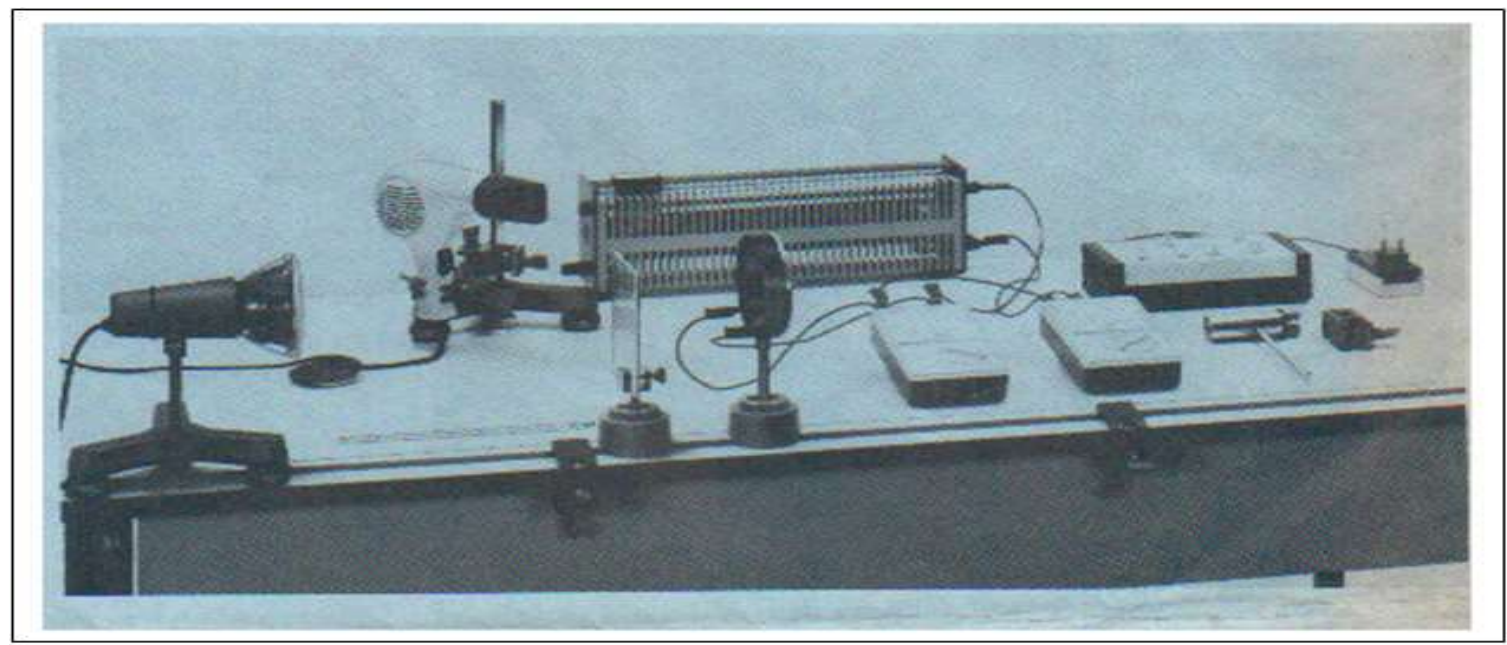

Fig (2) the Circuit of measuring photocurrent 


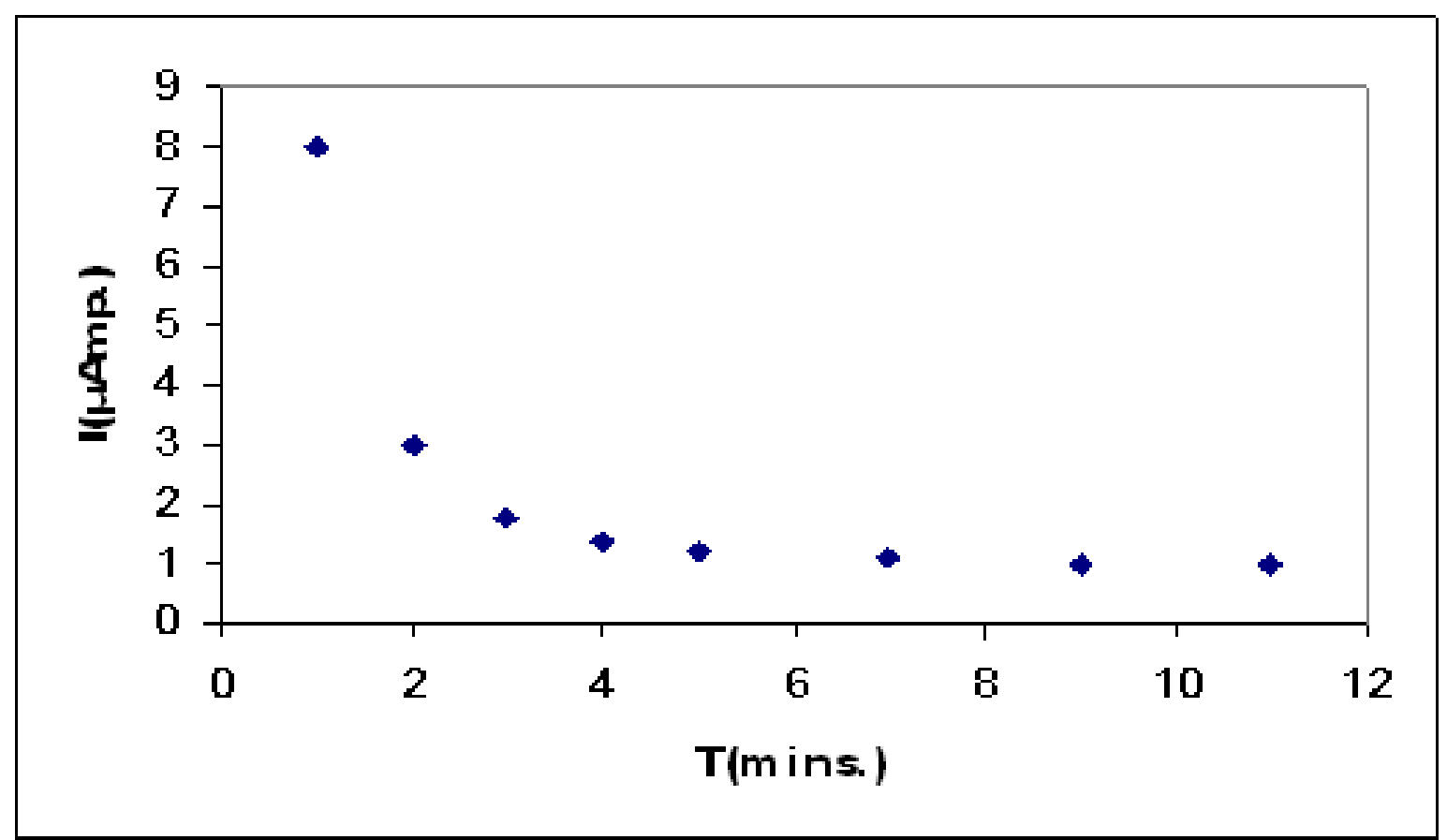

Fig (3) the variation of current as a function of time

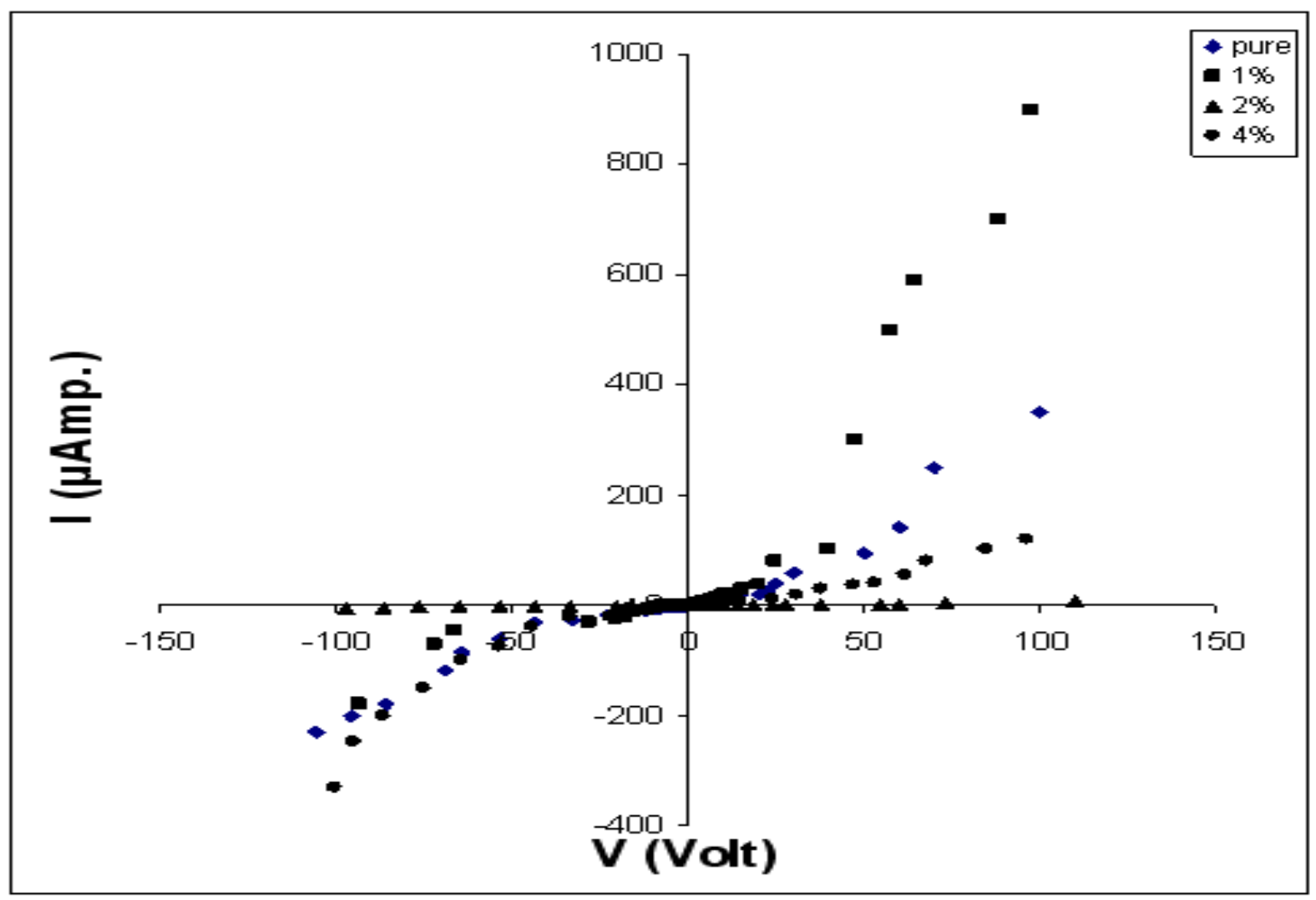

Fig (4)-(I-V) characteristics of the films at different doping ratio with iodine 


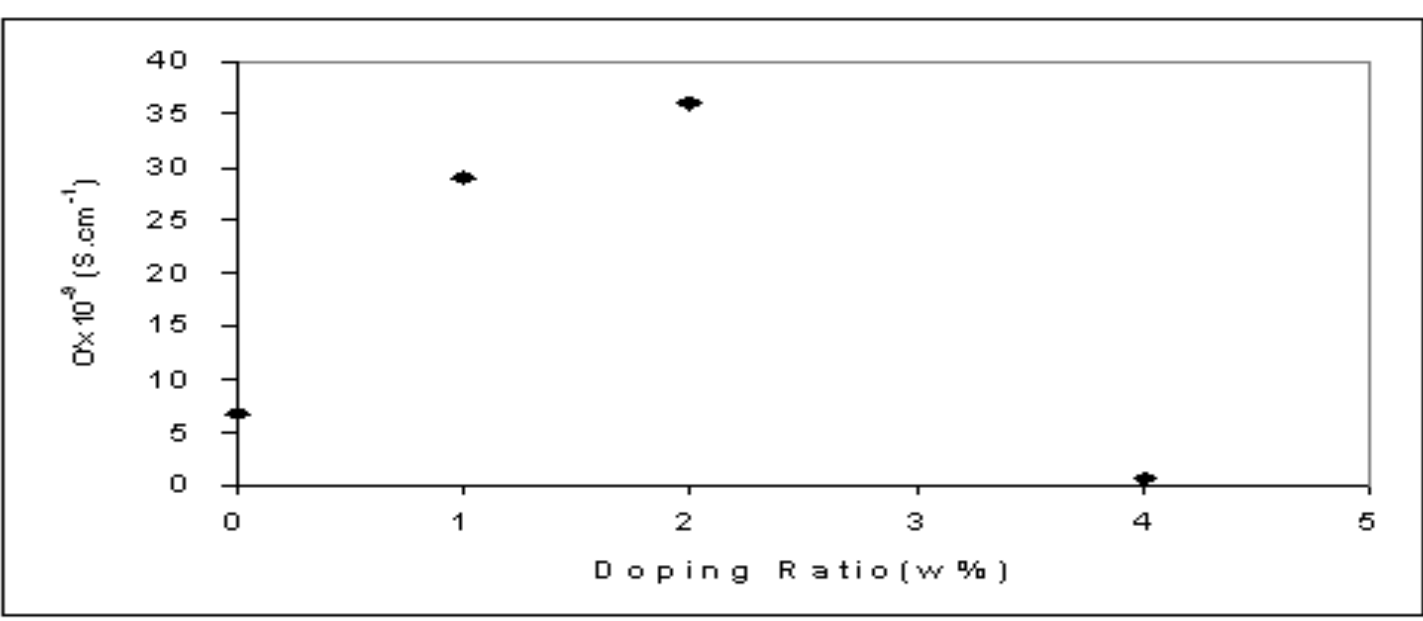

Fig (5) the variation of conductivity with doing ratio

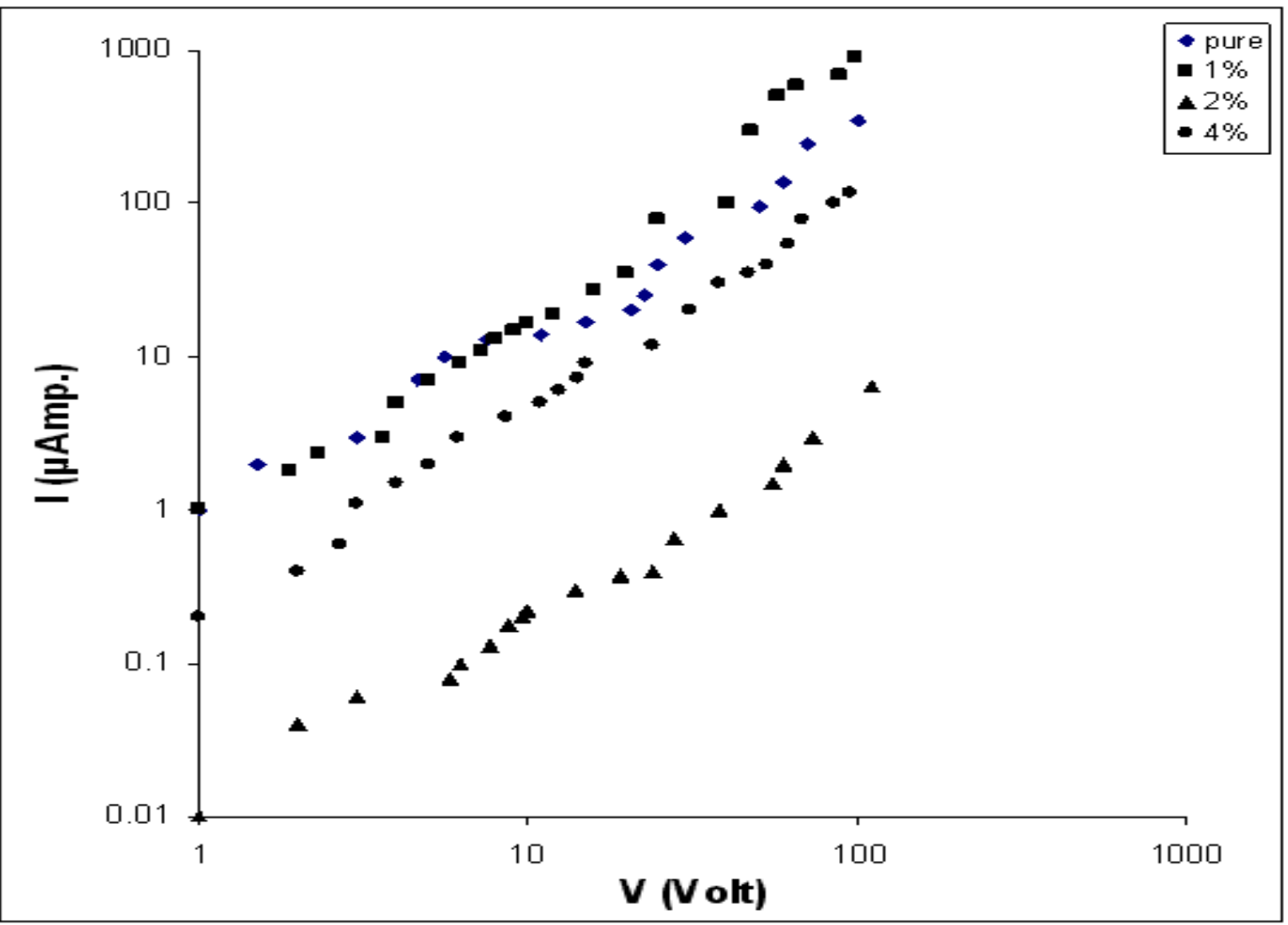

Fig (6) (LogI-LogV) characteristics of the films at different doping ratio with iodine 


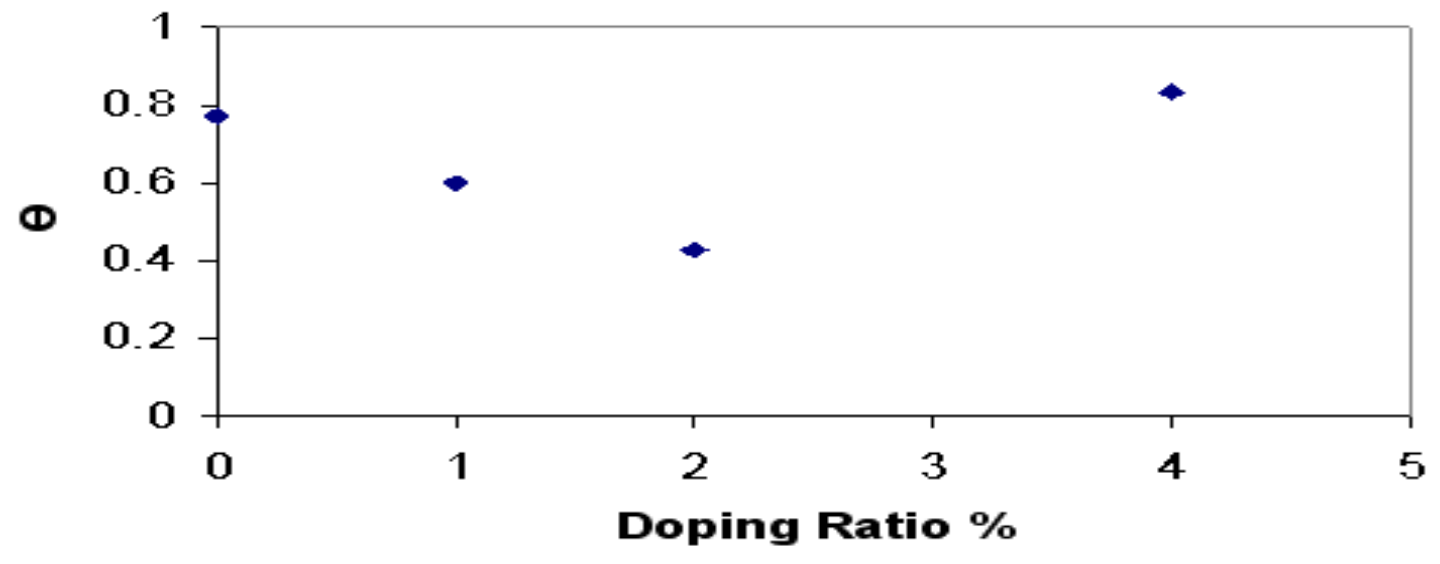

Fig (7) the variation of $\theta$ with doing ratio

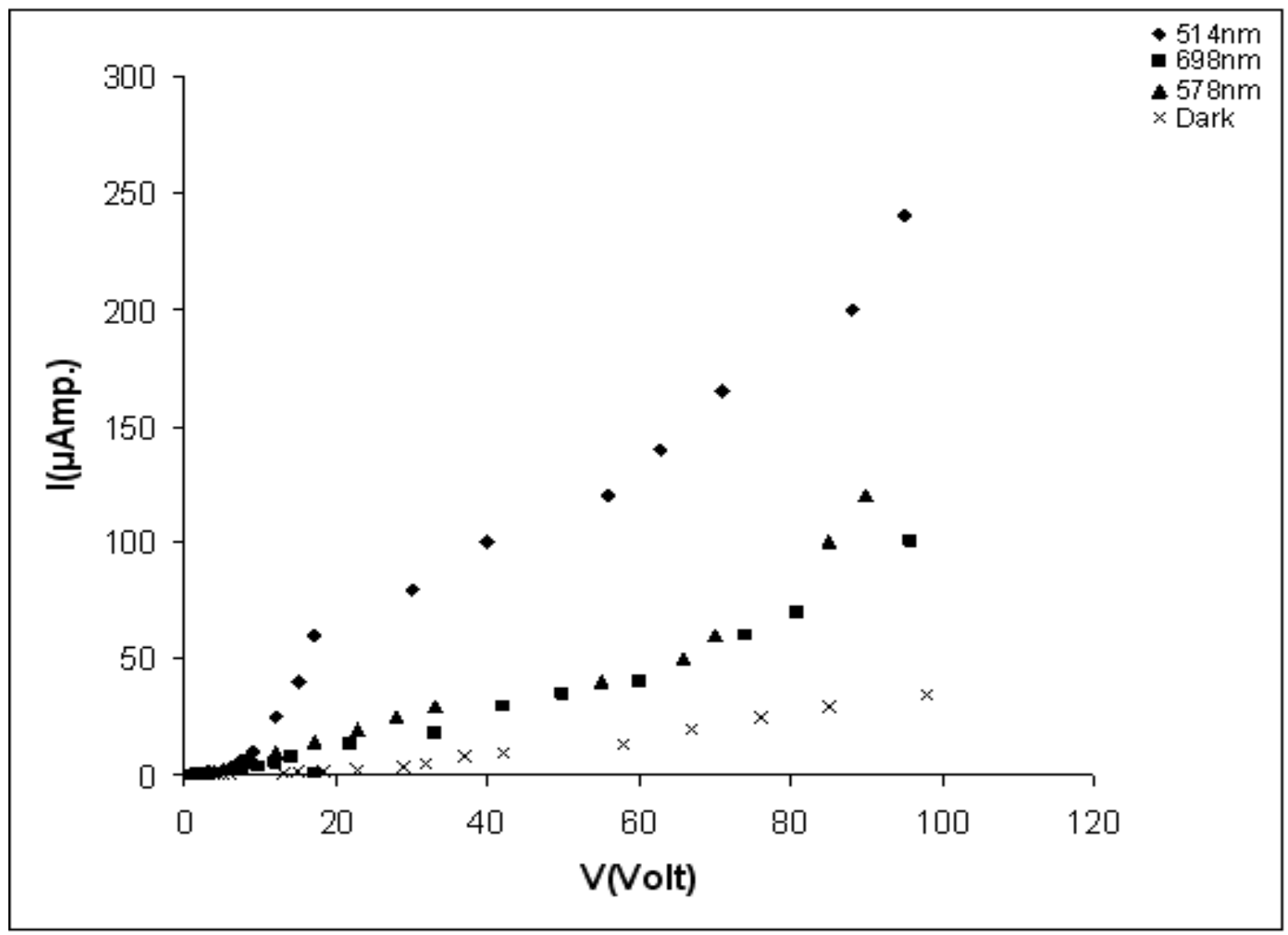

Fig (8)-(I-V ) characteristics of the films at different wave lengths of incident light 


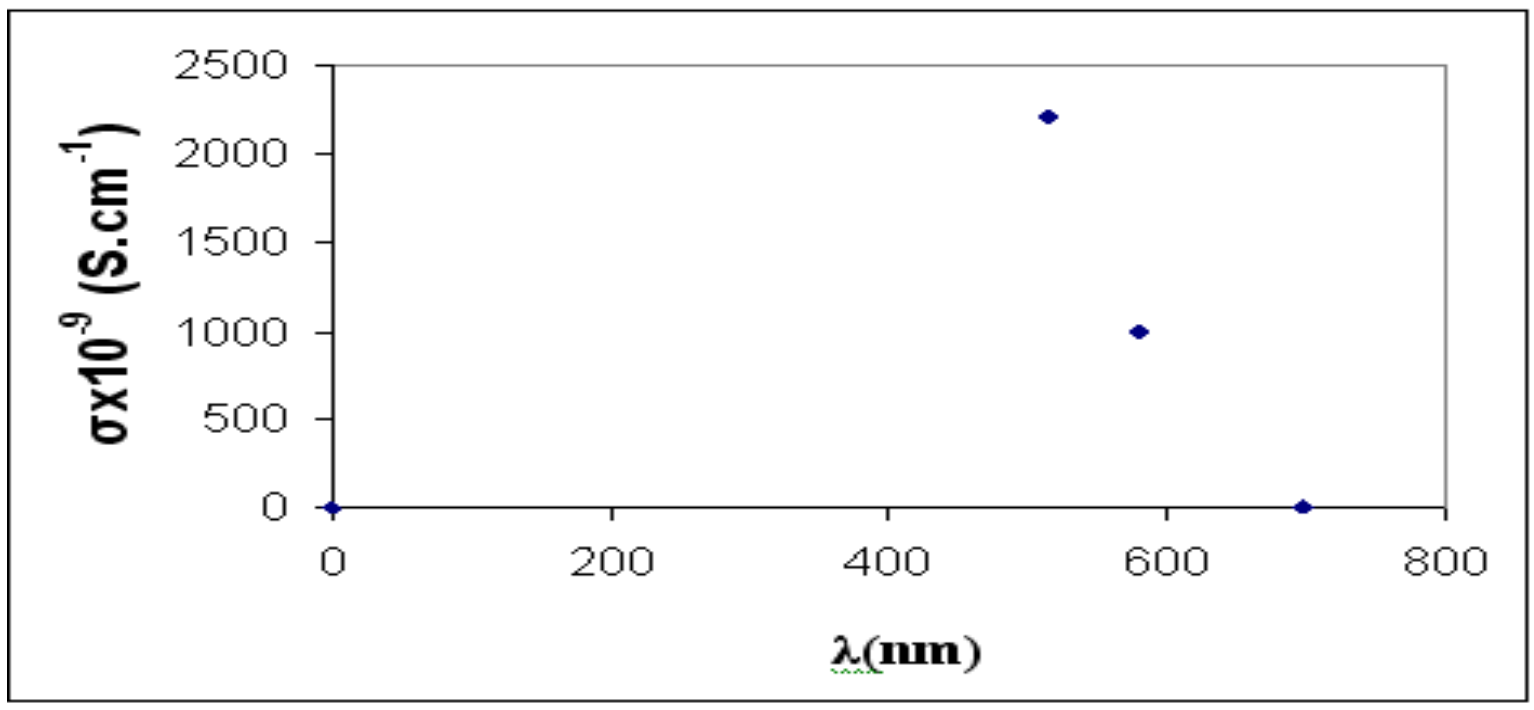

Fig (9) the variation of conductivity as a function of incident wave length

\section{References:}

1- H. Shirakawa, E.J. Louis, A.G. Macdiannid, C.K. Chiang and A.J. Heeger, J.Chem.Soc.Chem. Commun, B.16,(1977)578.

2- A.J. Heeger "Light Emission form Semiconducting Polymers: Light Emitting Diodes, Lightemitting Electrochemical Cells, Lasers, and White Light for the Future",Sol. State. Commun., 107, 111 (1998)

3- T.A. Shotheim, J.R. Rcynolds and R.L. Elswnbaumer, "Handbook of Conducting Polymers", $2^{\text {nd }}$ Edition, Marcel Dekker, New York, (1997).

4- J.H. Burroughes, D.D.C. Bradley, A.R. Brown, R.N. Marks, R.H. Friend, P.L. Burn and A.B. Holms, Nature, 347 (1990)539.

5- R.W. Gymer, R.H. Friend, A.B. Holms, E.G.J. Staring, C. Tatiani, D.D.C. Bradley, D.A. dos Santos, J.L. Brédas, M. Lögdlund and W.R. Salancck, Nature, 397 (1999)121.

6- R.W. Gymer, Endeavour, 20 (1996)115. 
7- J.R. Sheats, H. Antoniadis, M. Hueschen, W. Leonard, J. Mitter, R.Moon, D. Roitman and A. Stocking, Science, 273 (1996)884.

8- M. Berggren, O. Tnganäs, G. Gustafsson, J. Rasmusson, M.R. Andersson, T.Hjeriberg and O. Wennerström, Nature, 372 (1994) 444.

9- S. Tasch, C. Brandstätter, F. Mighdadi, G. Leising, G.Froyer and L. Athouil, Adv. Matery, 9 (1997)33.

10- Q.Pci, C.Yu, Y.Zhang and A.J. Heeger, Science, 269 (1995)1086.

11- N.S. Saricifici, L. Smilowiz, A.J. Heeger and F. Wudl, Science, 258 (1992)1474.

12- J.J.M. Halls, C.A. Walts, N.C. Greenham, E.A. Marseglia, R.H. Friend, S.C. Moratti and A.B. Holmes, Nature, 376 (1995)498.

13- F. Hide, M.A. Diaz-Garcia, B. Schwartz, M.R. Anderson and A.J. Heeger, Science, 1833 (1996)273.

14- N. Tessler, G.J. denton And R.H. Friend, Nature, 382 (1996)695.

12- Bidhan C.Roy, Maya Dutta Gupta, Leeua Bohumik, Jayanta K.Ray, Synthetic matels, 130 (2002) 27-33.

15- Wilso A.Gazotti, Jr., Marco-A.Depaoli, synthetic matels, 80(1996) 163-269.

16- R.Lgreene, G.B.Street and L.J.Suter, Phys.Rev.Lett., 34(1975)557.

17- Y.Cao, P.Smith, A.J.Heeger, Synthetic metals, 48(1992)91.

18- P.Dashora and G.Gupta, polymer vol.37, $2 \quad$ (1998) 231-239.

19- Y.Cao, P.smith, A.J.Heeger, Synthetic metals 57(1993)3514

20- J.Y.Lee, D.Y.Kim, C.Y.Kim, Synthetic Metals, 74(1995)103.

21- Yuichiro Ueno, G.S.Burgess, k., Preparation of 5-and 6-carboxyfluoresciene ,Practical synthetic Procedure 2004,31,(15),2591-2593

22- Noga E.j.,Udomkusonsri p.,(2002)."Fluoresciene:A Rapid Senstive Nonlethal Method for Detecting Skin Ulceration in Fish", Vetpathol 39:723 -731(6). PMID12450204.Retrieved on 200707-16.

23- The Diagnosis and management of Anaphlaxis -XXI.Anaphylactoid reaction to fluoresciene J. allergy Clin Immunol 1998;101:S465-528

24- 17-Y.Cao, P.smith, A.J.Heeger, Synthetic metals 57(1993)3514

25- J.Y.Lee, D.Y.Kim, C.Y.Kim, Synthetic Metals, 74(1995)103. 
دراسه الخواص الكهربائية والتيار الكهروضوئي لاغثية بولي انيلين المطعمة بصبغة

\author{
الفلورسين العضويه \\ حميد عبد الرزاق حمادي
}

جامعه البصره - مركز ابحاث البوليمر - قسم علوم المواد

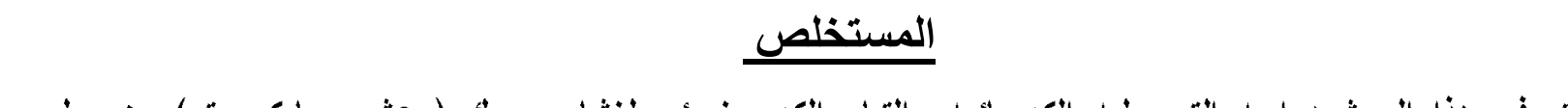

تم في هذا البحث دراسه التوصيليه الكهربائيه والتيار الكهروضوئي لفشاء سميك ( عشره مايكرومتر) من بوليمر الايلين المطعم بصبغه القلورسين العضويه يث تمت جميع القياسات الكهربائيه باستخدام تقينيه القطبين لقياس التوصيليه الكهربائيه وباستخذام قطبين من الالمنيوم علوي شبه شفاف وقطب المنيوم سفلي مع كون التيار الكهربائي المقاس في الحاله المستقزه وبينت الدراسه ان ميكاتيكيه التوصيل هي التيار المحد بشحنه الفراغ وان مقدار التوصيليه للاغشيه النقيه وتزداد هذه التوصيليه بمقار يقارب الخمسه مرات عند نسبه تثويب 6.6x10مساويه المى أثنان بالمائه وتم في هذا البحث زيضا تم قياس التيار الكهروضوئي كداله للجها الكهربائي المسلط وباستخدام مرشح ضوئي لطول موجي ثابت حيث كانت جميع القياسات عند مستوى شده مساوي الم 295 (2XL/M) حيث بينت النتائج المستحصله مقار التوصيله الكهزوضوئيه الضعيفه لاغشيه بوليمر الانيلين المطعده بصبغه الفلورسين على الرغم من تكون حاملات الشحنه (زوج الكترون - فجوه) وان اعلى توصيليه كهربائيه استحصلت بتسليط ضوء ذو طول موجي مقارب للصفر من الطيف المرئي نتيجه لزياده امتصاصيه الاغشيه وبالتالي زياده حاملات الثحنه وبينت التتائج المستحصله ان تردد العتبه لهذه الاغشيه هو قرب المنطقه الحمراء من الطيف المرئي ونتيجه لكون عمليات اعاده الاتحاد تحصل ضمن الغشاء ككل وان التوصيليه تزداد بمقار 1300 مره والتيار الكهروضوئي 800 مثارنه بالتيار عند عدم وجود ضوء . 